\title{
Re-understanding Personal and Organizational Mission with Netflix Cultural Manual
}

\author{
Yanyan Xu* \\ Teaching Quality Evaluation Center of Xi'an Eurasian University, Xi'an 710065, Shaanxi Province, China \\ *Corresponding author: Yanyan Xu, 59650293@qq.com
}

\begin{abstract}
Netflix first attracted domestic attention through an American drama, House of Cards, in 2013. In 2018, Netflix surpassed Disney in market value and became the world's largest media company. As a global streaming media giant, Netflix's corporate culture has always been sought after. Beginning with the eight principles of Netflix's culture, this article discusses the application of its culture in management to re-understand personal and organizational mission of modern enterprises.
\end{abstract}

Keywords: Netflix cultural manual; Corporate culture; Organizational mission; Personal mission

Publication date: June 2021; Online publication: June 30, 2021

\section{Introduction}

Netflix cultural manual, Powerful, was written by Patty McCord, the former chief talent officer of Netflix. The book revealed the cultural norms of the company. A great enterprise must have its own cultural genes, which gradually precipitate with the continuous development of business. The re-understanding of personal and organizational mission is inspired by the deep impression from the eight cultural norms in Netflix cultural manual.

\section{Only recruiting "adults"}

The author, McCord, mentioned at the beginning of her book that a great team is made up of each player knowing where they are going and is willing to make efforts to do so; building a great team does not depend on incentives, procedures, or benefits but on recruiting adults who are eager to accept challenges, and then communicating clearly and continuously with them about the challenges that would be encountered.

In modern enterprises, many managers believe that in order for employees to improve their productivity, they should use bonuses to motivate them. It has been a concept that high incentives would result in high value. However, for Netflix, the motivation for employees to work hard does not lie in incentives, procedures, or benefits but the real motivation lies in the process of accepting challenges, overcoming difficulties, achieving results, and a sense of achievement.

With regard to the term "adults" in the book, it implies certain behavioral patterns.

(1) Clear work objectives.

Matured employees have clear personal development goals, and they know where they want to go or what they want to achieve in their workplaces.

(2) Willing to make efforts.

With a career ideal, one must be able to put it into action. If there are only goals without actions, it is just an empty talk. Strong execution is the key. Only with dreams, hard work, and critical consciousness, one can develop better. Just as Inamori mentioned in his "Six Endeavors" to sharpen 
the mind, one should strive harder than anyone else, remain humble, reflect daily, appreciate life, make effort to do good deeds and serve others, as well as refusing to dwell on the past.

(3) Be brave to accept challenges.

Each and every person would encounter difficulties in their work. If a person is afraid of challenges and pressure, it would be difficult for that person to develop and grow. As adults, the courage to face and accept challenges, overcome difficulties, as well as forge ahead are requisites.

(4) Work to solve problems.

Everyone's needs are different. As mentioned in the motivation theory, motivation is people's conscious consciousness to pursue a certain expected purpose. Some people work for material benefits, others work for value recognition. For Netflix, those who work for success are the "adults" whom it recognizes. For matured employees, what enterprises should do is to create a fun environment for them by reducing the constraints of rules and regulations as well as giving them adequate room for growth. It is also important to communicate clearly and continuously with them about the challenges that would be encountered so as to ensure efficiency among team members for everyone to move forward synchronously.

\section{Encouraging everyone to understand the company's business}

The author mentioned of the value it would bring to the company if all employees have a unified understanding of the company's business. In Netflix, it has been a culture to pay great attention to cultivating the senior perspective of employees while ensuring transparent management and communication. Supervisors need to explain clearly and comprehensively to each employee regarding the reasons for the company's decisions, the best way that employees can participate in the realization of the company's objectives, and the obstacles that the company is facing.

It is understood that high performers can work better if they have a good understanding of the company's business. The book mentioned several measures, which are very valuable: establish a university for new employees and maintain a strong rhythm of communication; practice two way communication to provide employees the opportunity to ask questions; discussing with each employee of their experience with their customers which directly affects the company's profits; if given only a choice of course to train employees, it would be beneficial to the employees to know the basic knowledge of the company's business operation and customer service; the best benefit for employees is the opportunity to better understand the company's business and its customers.

This is a reminder of work, top-level strategic approach and guiding ideology, middle level understanding and implementation, as well as front-line employees' understanding and implementation. In the process of information transmission, there is attenuation. It is not easy for all employees to understand the strategic objectives of the enterprise and implement them correctly. Many jobs require the understanding from top to bottom in order to execute them properly. As the book has mentioned, "Only when employees are able to look at affairs from the perspective of senior managers, thus experiencing a real connection with the problems that must be solved at all levels and departments, can the company determine the problems and opportunities in each link and take effective measures."

\section{Only with absolute honesty, there will be efficient feedback}

One of the most important requirements of Netflix is that the employees need to talk about their problems openly; whether for grass-roots employees or senior managers, the requirement remains the same. It would be ideal if employees are able to communicate honestly anytime and anywhere in the company. If an 
employee has an opinion on another employee or the company, the best solution would be to communicate with the parties involved face to face. It would not be of any benefit to gossip behind each other's backs. This concept proposed in this chapter has some associations to the French thinker, Lenan, who mentioned, "Without freedom of thought, there is no science and no truth," as well as the Chinese writer, Colin, who mentioned, "Sincerity is the only way to truth." Advocating "absolute sincerity" is not only applicable to Netflix, but also to every organization. Working adults should act as "adults" and willingly accept the truth. In actual work, people tend to avoid excessive display of "human nature." In case of problems and errors, directly giving feedbacks to others would improve work efficiency and results.

\section{Only facts can defend opinions}

Everyone is allowed to have their own opinions. Many enterprises are also encouraging an open culture, but facts are facts. In Netflix, every employee is allowed to have his or her own point of view when encountering problems to defend their own opinions. However, opinions should always be based on facts; opinions without facts are worthless. A great danger in business is that some people win arguments because of their strong persuasion rather than relying on factual views.

This is often the case, especially during meetings. Everyone is allowed to brainstorm and put forward their own ideas. However, when making decisions, objectivity and rationality should be present while defending opinions with facts.

\section{Start building the future team now}

Netflix attaches great importance to recruitment as its interviews are given higher value than any other determined meeting. This is to show respect for talents. It is widely understood that candidates are evaluating the company just as the representatives of the company are evaluating them. McCord have stated that employees are responsible for their own growth. Managers should not regard themselves as career planners for their employees. The most important thing managers should do is to ensure that the company can produce good products and serve customers well. Therefore, it is necessary to constantly search for talents and reconfigure the team.

The measure of the number of talents with skills and experience should be the goal of an excellent team. It is necessary to build a great team and complete work on time. Netflix encourages its employees to try out new things, make mistakes, be brave to start again, and finally reap results.

\section{Highly matching positions in employment}

In regard to Netflix's talent management, the recruitment of a highly matched person is necessary for each post. If an employee's skills no longer match the job requirements, even excellent talents should bid the post farewell. Retaining talents is not the goal of team building. The key indicator is whether a highly matched and future oriented team can be established.

Human resource specialists need to have a good insight in order to recruit the right talents, placing them in the most suitable posts, as well as maximize personal value and organizational development.

\section{Paying according to the value brought by employees}

In determining an employee's salary, Netflix does not consider the employee's previous salary. If the employee performs excellently, he or she would be paid according to the value brought to the company, not necessarily according to the internal salary standard. This is to protect the interests of the best contribution value. For on-the-job employees, Netflix also measures the value of their jobs and provides the highest salary of the same position in the market. The company even encourages its employees to 
arrange for interviews at other companies so that the employees would be able to gauge the salary competitiveness.

Netflix's salary system is also different from most companies. Timely salary is completely transparent. Its salary system is completely transparent, and employees can understand the basis behind the salary difference. Contributing more to the company ensues a higher salary. In the same way, if an employee did not contribution much to the company, his or her salary will naturally be lower in comparison to those who have contributed more.

\section{Saying goodbye when leaving}

Netflix believes that a company is a team rather than a home. Netflix has established a two-way flow team. On the one hand, the search for the best people in the market and the best match with Netflix is continuous. On the other hand, Netflix does not force its employees to stay. Its' concept is that it is good to gather and disperse. Netflix wants the employees to feel as if it is still a great company even after they have left. As mentioned, Netflix regards the company as a team, not a family. The importance of this concept is that the goal of the team is to win. Therefore, whether the team can win the game is the only standard to measure the success of a team. With that concept in mind, the coach will replace the players who cannot produce the best results in time.

Netflix believes that this method has more advantages than disadvantages for both the employees and the company. For employees, they would be able to gauge their real working status and competitiveness, thus enabling them to make appropriate adjustments and saving time before being completely eliminated. In addition, if an employee's skills do not match the position, he or she would have to work very hard. In view of that, that employee would probably leave to look for a more suitable company to develop better.

\section{Conclusion}

Netflix's cultural norms are related to the nature of the enterprise. These norms are interdependent and promote each other to form an organic whole. These norms make people feel both warm and powerful. They are norms that stimulate human potential and humanistic thought, not relying on systems and administrative instructions. Definitely, an excellent corporate culture cannot be achieved overnight. It is based on systems, rules, and processes, which are solidified first and then optimized. In order to learn from the experiences of others, it is essential to restore them to their background in order to understand what can be learned and what cannot. At the same time, the key value of learning lies in the application, reflection, and improvement of one's current work. For modern enterprises, there is a need to pay attention to the changes of the external environment, customers, and internal employees while being vigilant and sharp as well as embracing changes calmly.

\section{Disclosure statement}

The author declares that there is no conflict of interest.

\section{References}

[1] McCord P, 2018, Naifei Culture Manual. Zhejiang Education Press, Hangzhou, 17.

[2] Naifei's Eight Principles of Corporate Culture. Management Abstracts, (128). 